\title{
Two-Stage Sensing Property via a Conjugated Donor-Acceptor-Donor Constitution: Application to the Visual Detection of Mercuric Ion
}

\author{
Ju-Hui Huang, ${ }^{\dagger}$ Wen-Hsien Wen ${ }^{\dagger}{ }^{\text {Yueh-Yang Sun }},{ }^{\dagger}$ Pi-Tai Chou, ${ }^{\dagger}$ and Jim-Min Fang ${ }^{*}, \dagger$, \\ Department of Chemistry, National Taiwan University, Taipei 106, Taiwan, and Genomics Research \\ Center, Academia Sinica, Taipei 115, Taiwan
}

jmfang@ntu.edu.tw

Received March 2, 2005

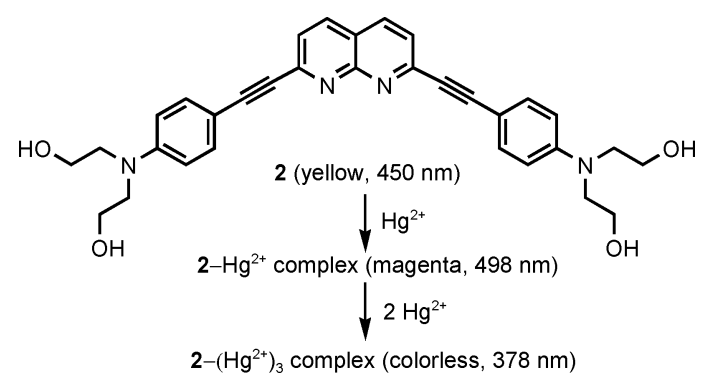

A conjugated donor-acceptor-donor molecule incorporating a central moiety of naphthyridine and two terminal moieties of di(hydroxyethyl)aniline connected by ethynyl bridges shows two-stage color changes on binding with mercury(II) ion in $\mathrm{Me}_{2} \mathrm{SO} / \mathrm{H}_{2} \mathrm{O}$ (1:1) solution with a bathochromic shift from 450 to $498 \mathrm{~nm}$, and then an extraordinarily large hypsochromic shift to $378 \mathrm{~nm}$. In comparison, the corresponding donor-acceptor molecule weakly binds mercury(II) ion with a hypsochromic shift from 408 to $375 \mathrm{~nm}$. Our designed sensor of the donor-acceptor-donor system shows high selectivity toward mercury(II) ion over other competing metal ions.

\section{Introduction}

A molecule bearing conjugated electron acceptor (A) and electron donor (D) usually undergoes an intramolecular charge transfer (ICT) upon electronic excitation. ${ }^{1}$ The ICT and hence an elongation of the $\pi$ electron conjugation occurring upon Franck Condon excitation contributes considerably to the absorption profile. If the $\mathrm{A}-\mathrm{D}$ molecule binds a metal ion at the acceptor site, a bathochromic shift occurs to account for the enhanced ICT. ${ }^{1,2}$ However, in most cases, a metal ion tends to bind at the electron-rich donor site to cause a hypsochromic shift, often making visual detection difficult., ${ }^{1,2}$ To extend the $\mathrm{A}-\mathrm{D}$ recognition concept, the optical properties and binding behavior of $\mathrm{D}-\mathrm{A}-\mathrm{D}$ molecules are of interest to investigate, because they may be employed in multiplestage sensing of appropriate analytes over a large dynamic range of concentration. ${ }^{1,2}$

\footnotetext{
$\dagger$ National Taiwan University.

\# Academia Sinica.

(1) (a) de Silva, A. P. H.; Gunaratne, Q. N.; Gunnlaugsson, T.; Huxley, A. J. M.; McCoy, C. P.; Rademacher, J. T.; Rice, T. E. Chem. Rev. 1997, 97, 1515-1566. (b) Valeur, B.; Leray, I. Coord. Chem. Rev. 2000, 205, 3-40. (c) Rurack, K. Spectrochim. Acta Part A 2001, 57, $2161-2195$.
}

We have previously explored that 2,7-bis(1H-pyrrol-2yl)ethynyl-1,8-naphthyridine (BPN), a push-pull conjugated molecule, exhibits a very large Stokes shift of fluorescence upon complexation with glucopyranoside. ${ }^{3}$ Along this line, we herein designed the molecule 2 of $\mathrm{D}-\mathrm{A}-\mathrm{D}$ assembly, in comparison with molecule $\mathbf{1}$ of $\mathrm{A}-\mathrm{D}$ constitution, as a simple model to demonstrate the concept of the two-stage sensing with enhanced signal transduction. ${ }^{4}$ As shown by the schematic drawing (Scheme 1), the naphthyridine moiety acts as the acceptor site, whereas the di(hydroxyethyl)amino moiety functions

(2) (a) Wang, S.-L.; Ho, T.-I. Chem. Phys. Lett. 1997, 268, 434-438. (b) Gao, C.; Brümmer, O.; Mao, S.; Janda, K. D. Org. Lett. 1999, 1, 415-418. (c) Rurack, K.; Sczepan, M.; Spieles, M.; Resch-Genger, U. Rettig, W. Chem. Phys. Lett. 2000, 320, 87-94. (d) Crochet, P.; Malval J.-P.; Lapouyade, R. Chem. Commun. 2000, 289. (e) Brümmer, O.; La Clair, J. J.; Janda, K. D. Bioorg. Med. Chem. 2001, 9, 1067-1071. (f) Palomares, E.; Vilar, R.; Durrant, J. R. Chem. Commun. 2004, 362363. (g) Gunnlaugsson, T.; Leonard, J. P.; Murray, N. S. Org. Lett. 2004, 6, 1557-1560. (h) El-Gezawy, H.; Rettig, W.; Lapouyade, R. Chem. Phys. Lett. 2005, 401, 140-148.

(3) (a) Liao, J.-H.; Chen, C.-T.; Chou, H.-C.; Cheng, C.-C.; Chou, P.T.; Fang, J.-M.; Slanina, Z.; Chow, T. J. Org. Lett. 2002, 4, 3107-3110. (b) Fang, J.-M.; Selvi, S.; Liao, J.-H.; Slanina, Z.; Chen, C.-T.; Chou, P.-T. J. Am. Chem. Soc. 2004, 126, 3559-3566. 
SCHEME 1. Design of Metal Ion Sensor with Conjugated A-D and D-A-D Assemblies

(a)

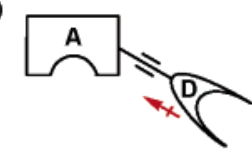

Sensor of A-D assembly
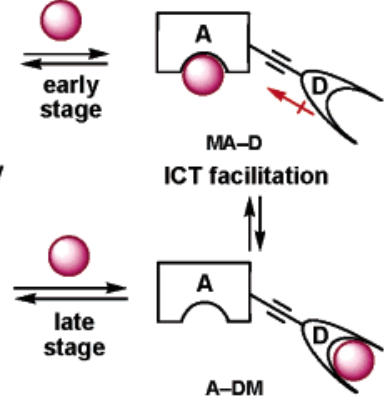

ICT diminution

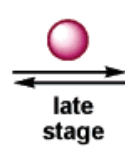

ICT diminution (b)
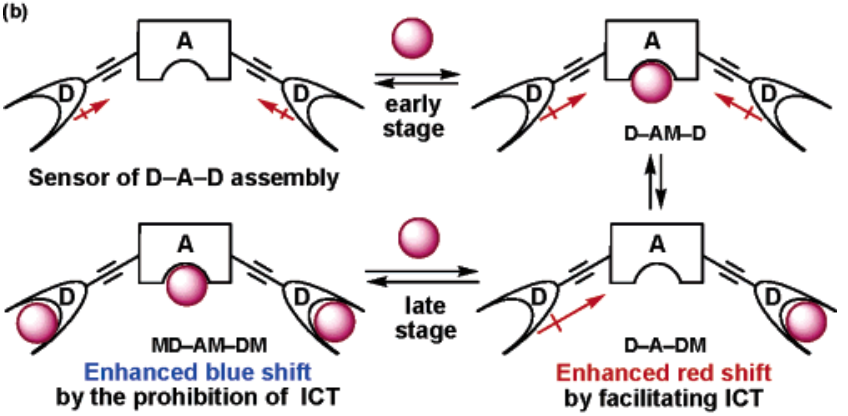

by the prohibition of ICT

A : acceptor

D : donor

as the donor site. The acceptor and donor moieties are connected by ethynyl bridges to form a conjugated scaffold.
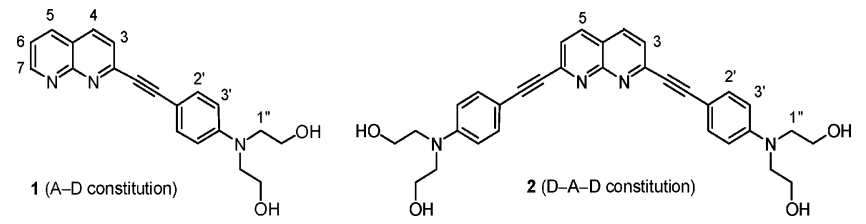

In general, several binding states may exist in equilibrium. The degree of $\pi$ electron conjugation induced by ICT, in a qualitative sense, can be designated by the dipolar vector depicted in Scheme 1. For example, the binding of the $\mathrm{A}-\mathrm{D}$ molecule with a metal ion at the acceptor site, forming MA-D, would enhance the acceptor strength to facilitate ICT, whereas the binding at the donor site, forming A-DM, would reduce ICT. When both the acceptor and donor sites are bound to metal ions, the original donor group D is changed to an electronwithdrawing group DM, and the dipole would diminish. According to the preference of binding states in equilibrium, a bathochromic shift might be attributed to the ICT increase, and a hypsochromic shift might be attributable to the ICT diminution.

The binding event of the $\mathrm{D}-\mathrm{A}-\mathrm{D}$ molecule with metal ions would be much more complicate than that for the A-D molecule. However, a simplified book-keeping mech-

(4) (a) Fery-Forgues, S.; Le Bris, M.-T.; Guetté, J.-P.; Valeur, B. J. Phys. Chem. 1988, 92, 6233-6237. (b) Rurack, K.; Rettig, W.; ReschGenger, U. Chem. Commun. 2000, 407-408. (c) Rurack, K.; Koval'chuck, A.; Bricks, J. L.; Slominskii, J. L. J. Am. Chem. Soc. 2001, 123, 62056206. (d) Marcotte, N.; Plaza, P.; Lavabre, D.; Fery-Forgues, S.; Martin, M. M. J. Phys. Chem. A 2003, 107, 2394-2402. anism can be drawn by focusing on the two major stages (the early and late stages) as shown in Scheme 1b. At the early stage, the $\mathrm{D}-\mathrm{A}-\mathrm{D}$ molecule may bind with a metal ion, either at the acceptor or at the donor sites, to form 1:1 complexes. An increase of ICT is obvious in the binding at the acceptor site, forming $\mathrm{D}-\mathrm{AM}-\mathrm{D}$, due to the enhanced acceptor strength. When a metal ion binds at one of the donor sites, the resulting A-DM unit may also function as an enhanced electron-withdrawing group to facilitate ICT, a consequence differing from the binding of the $\mathrm{A}-\mathrm{D}$ molecule at the donor site. Therefore, one can predict that the binding of the $\mathrm{D}-\mathrm{A}-\mathrm{D}$ molecule with a metal ion at the early stage will cause a bathochromic spectral shift, regardless of the binding at the acceptor or donor site. When the $\mathrm{D}-\mathrm{A}-\mathrm{D}$ molecule is saturated with metal ions at the late stage, all the acceptor and donor sites are bound to metal ions to form a 1:3 complex (MD-AM-DM). A hypsochromic spectral shift thus occurs to account for the great decrease of dipole at this stage.

\section{Results and Discussion}

Two consecutive Sonogashira coupling reactions were applied to synthesize sensor molecules $\mathbf{1}$ and $\mathbf{2}$ (Scheme 2 ). The coupling reaction of $N, N$-di(2-hydroxyethyl)-4iodoaniline with (trimethylsilyl)acetylene was promoted by $10 \mathrm{~mol} \%$ of $\mathrm{PdCl}_{2}\left(\mathrm{PPh}_{3}\right)_{2}$ and $\mathrm{CuI}$ in the presence of $\mathrm{Et}_{3} \mathrm{~N}$ to give 3, after a subsequent removal of the trimethylsilyl group by $\mathrm{K}_{2} \mathrm{CO}_{3}$. Under similar conditions, coupling of 3 with 1 equiv of 2-chloro-1,8-naphthyridine gave sensor 1 , whereas that with 0.5 equiv of 2,7 -dichloro1,8-naphthyridine afforded sensor 2.

The solution of molecule $\mathbf{1}$ in $\mathrm{Me}_{2} \mathrm{SO} / \mathrm{H}_{2} \mathrm{O}$ (1:1) solution showed the absorption maximum at $408 \mathrm{~nm}(\epsilon=45000$ $\mathrm{M}^{-1} \mathrm{~cm}^{-1}$ ) (Figure 1), whereas the dual-armed molecule 2 exhibited the absorption maximum at a much longer wavelength, $\lambda_{\max }=450 \mathrm{~nm}\left(\epsilon=54000 \mathrm{M}^{-1} \mathrm{~cm}^{-1}\right.$ ) (Figure 2). The large red-shift $(42 \mathrm{~nm})$ from 1 of the $A-D$ constitution to $\mathbf{2}$ of the $\mathrm{D}-\mathrm{A}-\mathrm{D}$ constitution may be tentatively rationalized by the ethynyl substituent effect in one of the arms of $\mathbf{2}$, which, in part, elongates the $\pi$ conjugation upon exciting the other $\mathrm{A}-\mathrm{D}$ chromophore. However, the possibility of exciton coupling due to the crosstalk of two chromophores cannot be excluded at this stage.

Both the naphthyridine ${ }^{5}$ and di(hydroxyethyl)aniline ${ }^{6}$ moieties are known to have affinity toward metal ions. During our preliminary screening, molecules $\mathbf{1}$ and $\mathbf{2}$ were found to bind $\mathrm{Hg}^{2+}$ ions in aqueous media (e.g. $\mathrm{Me}_{2-}$ $\mathrm{SO} / \mathrm{H}_{2} \mathrm{O}=1: 1$ ). The pollution of mercury and its derivatives has posed severe problems for human health and the environment. ${ }^{7}$ Many methods have been developed to detect $\mathrm{Hg}^{2+}$ ion. ${ }^{2,8}$ In our study, the stock solutions of 1 and $2\left(1 \times 10^{-5} \mathrm{M}\right)$ in $\mathrm{Me}_{2} \mathrm{SO} / \mathrm{H}_{2} \mathrm{O}$ (1:1) were prepared,

(5) (a) Boelrijk, A. E. M.; Neenan, T. X.; Reedijk, J. J. Chem. Soc., Dalton Trans. 1997, 4561-4570. (b) He, C.; Lippard, S. J. Inorg. Chem. 2000, 39, 5225-5231. (c) Catalano, V. J.; Kar, H. M.; Bennett, B. L. Inorg. Chem. 2000, 39, 121-127. (d) He, C.; Lippard, S. J. Inorg. Chem. 2001, 40, 1414-1420.

(6) Kubo, K.; Sakurai, T.; Mori, A. Talanta 1999, 50, 73-77.

(7) (a) Morel, F. M. M.; Kraepiel, A. M. L.; Amyot, M. Annu. Rev. Ecol. Syst. 1998, 29, 543-566. (b) Guidelines for Drinking-Water Quality, 2nd ed.; World Health Organization: Geneva, 1996; Vol. 2, p 940 . 
SCHEME 2. Synthesis of Conjugated A-D and D-A-D Sensors 1 and $2^{a}$
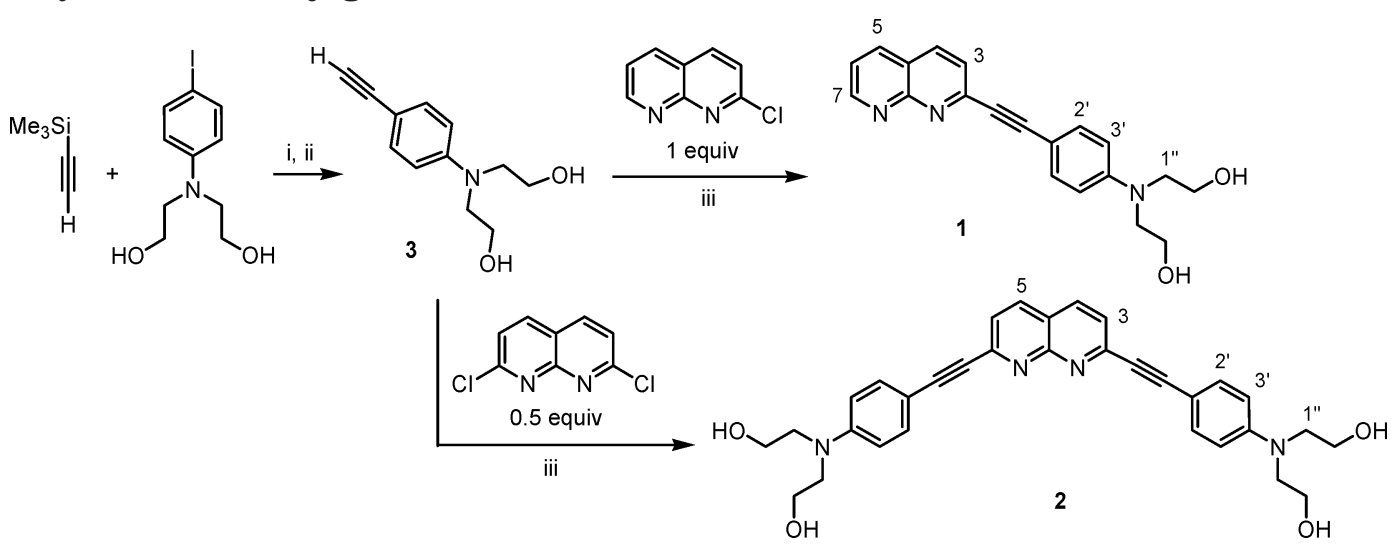

${ }^{a}$ Reagents and reaction conditions: (i) $\mathrm{PdCl}_{2}\left(\mathrm{PPh}_{3}\right)_{2}$, $\mathrm{CuI}, \mathrm{Et} 3{ }_{3} \mathrm{~N}, 1$,4-dioxane, $50{ }^{\circ} \mathrm{C}, 14 \mathrm{~h}$. (ii) $\mathrm{K}_{2} \mathrm{CO}_{3}, \mathrm{MeOH}, \mathrm{rt}, 1 \mathrm{~h}$; $82 \%$ yield for two steps. (iii) $\mathrm{PdCl}_{2}\left(\mathrm{PPh}_{3}\right)_{2}, \mathrm{CuI}, \mathrm{Et}_{3} \mathrm{~N}, \mathrm{DMF}, 80^{\circ} \mathrm{C}, 18 \mathrm{~h} ; 82 \%$ yield for 1 and $13 \mathrm{~h} ; 77 \%$ yield for 2.

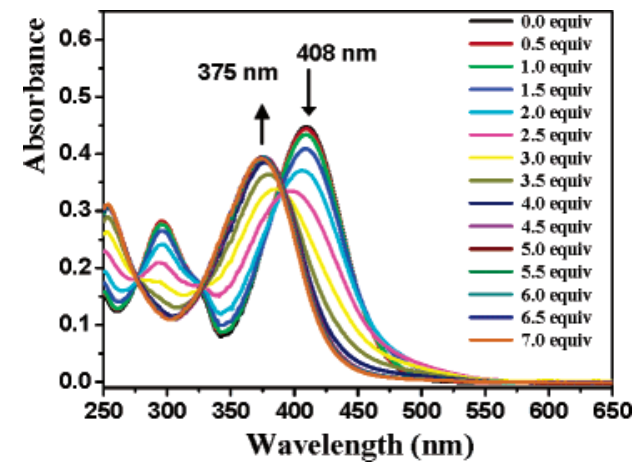

FIGURE 1. UV-vis titration of the $\mathrm{A}-\mathrm{D}$ receptor $\mathbf{1}\left(1 \times 10^{-5}\right.$ $\mathrm{M})$ in $\mathrm{Me}_{2} \mathrm{SO} / \mathrm{H}_{2} \mathrm{O}$ (1:1) solution with various amounts of $\mathrm{Hg}^{2+}$ ions $\left(1 \times 10^{-2} \mathrm{M}\right.$ in distilled water).

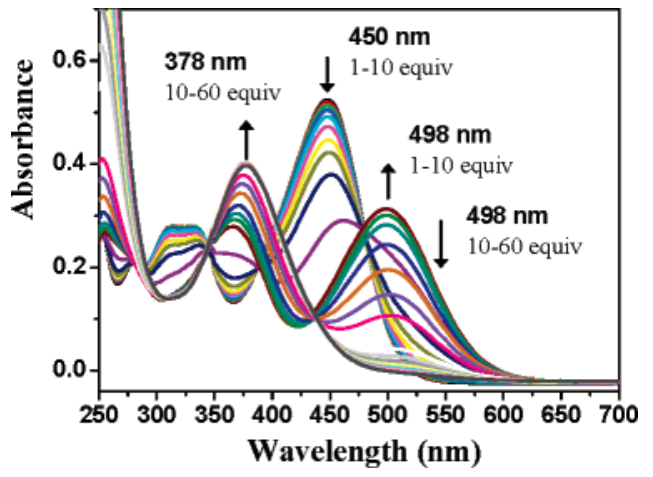

FIGURE 2. UV-vis titration of the $\mathrm{D}-\mathrm{A}-\mathrm{D}$ receptor $\mathbf{2}(1 \times$ $10^{-5} \mathrm{M}$ in $\mathrm{Me}_{2} \mathrm{SO} / \mathrm{H}_{2} \mathrm{O}, 1: 1$ ) with various amounts of $\mathrm{Hg}^{2+}$ ion $\left(1 \times 10^{-2} \mathrm{M}\right.$ in distilled water $)$.

and the binding event was monitored by the UV-vis spectroscopic method. The titrations were carried out by using various amounts of $\mathrm{Hg}^{2+}$ ion as the aqueous solution of perchlorate salt.

The binding of $\mathbf{1}$ with $\mathrm{Hg}^{2+}$ was rather weak; only after addition of more than 1 equiv of $\mathrm{Hg}^{2+}$ ions did a new blueshifted absorption band at $\lambda_{\max }=375 \mathrm{~nm}$ appear and increase at the expense of the $408 \mathrm{~nm}$ band (Figure 1). This hypsochromic shift is ascribed to the preferable binding of $\mathrm{Hg}^{2+}$ ion at the donor site of di(hydroxyethyl)aniline, as the $\mathrm{A}-\mathrm{DM}$ species in Scheme $1 \mathrm{a},{ }^{1,2,8}$ or complexation at both the acceptor and donor sites, as the MA-DM species with diminution of ICT. When $\leq 1$ equiv of $\mathrm{Hg}^{2+}$ ions was added to $\mathbf{1}$, a very weak absorption occurring at $\sim 500 \mathrm{~nm}$ might be attributable to a transient binding of $\mathrm{Hg}^{2+}$ ion at the acceptor (naphthyridine) site, as the enhanced ICT species of AM-D in Scheme 1a.

The ${ }^{1} \mathrm{H}$ NMR titration study of 1 in $\mathrm{Me}_{2} \mathrm{SO}-d_{6}$ solution (see Figure S1 in the Supporting Information) indicated that the initial addition of $\mathrm{Hg}^{2+}$ ions $\left(<0.5\right.$ equiv in $\mathrm{CD}_{3^{-}}$ $\mathrm{CN}$ ) caused the disappearance of the hydroxyl protons and significant downfield shifts of the protons on the naphthyridine ring, but no apparent change of the protons on the di(hydroxyethyl)aniline moiety. The ${ }^{1} \mathrm{H}$ NMR spectra became complicated on further addition of $\mathrm{Hg}^{2+}$ ions (1-4 equiv in this study), presumably due to existence of several complexation species. According to the chemical-shift changes of $\mathrm{H}-7$, from $\delta 9.08$ to 9.20 during the titration, the association constant $\left(K_{\text {ass }}\right)$ of $1490 \pm 31$ for $\mathbf{1}-\mathrm{Hg}^{2+}(1: 1$ complex $)$ at $298 \mathrm{~K}$ in $\mathrm{Me}_{2} \mathrm{SO}-$ $d_{6}$ solution was deduced by the nonlinear regression method. ${ }^{9}$

(8) (a) Chae, M.-Y.; Czarnik, A. W. J. Am. Chem. Soc. 1992, 114 9704-9705. (b) Hennrich, G.; Sonnenschein, H.; Resch-Genger, U. J. Am. Chem. Soc. 1999, 121, 5073-5074. (c) Rurack, K.; Resch-Genger, U.; Bricks, J. L.; Spieles, M. Chem. Commun. 2000, 2103-2104. (d) Sakamoto, H.; Ishikawa, J.; Nakao, S.; Wada, H. Chem. Commun. 2000, 2395-2396. (e) Rurack, K.; Kollmannsberger, M.; Resch-Genger, U.; Daub, J. J. Am. Chem. Soc. 2000, 122, 968-969. (f) Prodi, L.; Bargossi, C.; Montalti, M.; Zaccheroni, N.; Su, N.; Bradshaw, J. S.; Izatt, R. M.; Savage, P. B. J. Am. Chem. Soc. 2000, 122, 6769-6770. (g) Hassan, S. S. M.; Saleh, M. B.; Abdel, G.; Ahmed, A.; Mekheimer, R. A. H.; Abdel, K.; Nahed, A. Talanta 2000, 53, 285-293. (h) Al Shihadeh, Y.; Benito, A.; Lloris, J. M.; Martinez-Manez, R.; Pardo, T.; Soto, J.; Marcos, M. D. J. Chem. Soc., Dalton Trans. 2000, 7, 11991205. (i) Das, A. K.; de la Guardia, M.; Cervera, M. L. Talanta 2001, 55, 1-28. (j) Sancenon, F.; Martynez-Manez, R.; Soto, J. Chem. Commun. 2001, 2262-2263. (k) Padilla-Tosta, M. E.; Lloris, J. M.; Martinez-Manez, R.; Marcos, M. D.; Miranda, M. A.; Pardo, T.; Sancenon, F.; Soto, J. Eur. J. Inorg. Chem. 2001, 1475-1482. (1) Sancenon, F.; Martynez-Manez, R.; Soto, J. Tetrahedron Lett. 2001, 42, 4321-4323. (m) Cha, N. R.; Kim, M. Y.; Kim, Y. H.; Choe, J.-I.; Chang, S.-K. J. Chem. Soc., Perkin Trans. 2 2002, 1193-1196. (n) Descalzo, A. B.; Martinez-Manez, R.; Radeglia, R.; Rurack, K.; Soto, J. J. Am. Chem. Soc. 2003, 125, 3418-3419. (o) Nolan, E. M.; Lippard, S. J. J. Am. Chem. Soc. 2003, 125, 14270-14271. (p) Caltagirone, C.; Bencini, A.; Demartin, F.; Devillanova, F. A.; Garau, A.; Isaia, F.; Lippolis, V.; Mariani, P.; Papke, U.; Tei, L.; Verani, G. J. Chem. Soc., Dalton Trans. 2003, 901-909. (q) Moon, S. Y.; Cha, N. R.; Kim, Y. H.; Chang, S.-K. J. Org. Chem. 2004, 69, 181-183. (r) Guo, X.; Qian, X.; Jia, L. J. Am. Chem. Soc. 2004, 126, 2272-2273. (s) Metivier, R.; Leray, I.; Valeur, B. Chem. Eur. J. 2004, 10, 4480-4490. (t) Palomares, E.; Vilar, R.; Durrant, J. R. Chem. Commun. 2004, 362-363. 


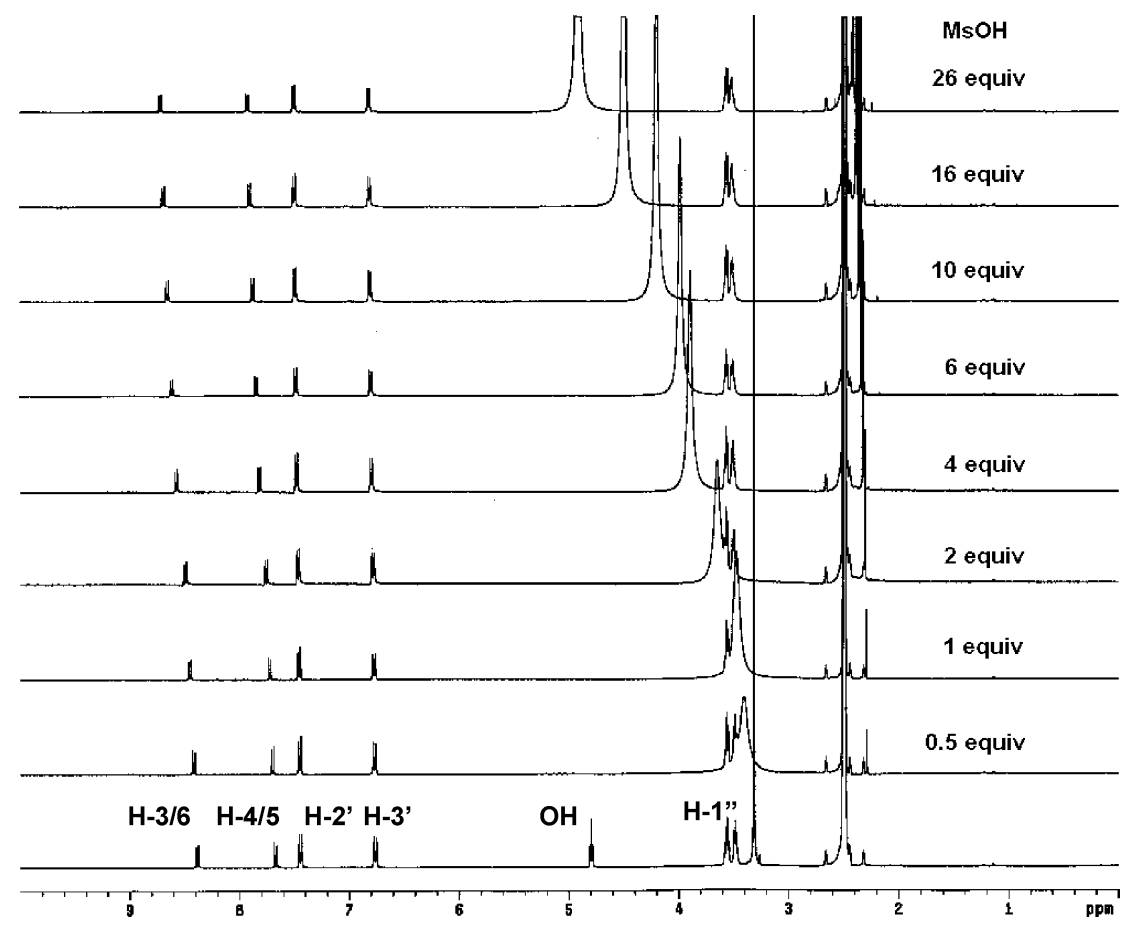

FIGURE 3. ${ }^{1} \mathrm{H}$ NMR titration of $2\left(2.5 \times 10^{-3} \mathrm{M}\right.$ in $\left.\mathrm{Me}_{2} \mathrm{SO}-d_{6}\right)$ by incremental additions of $\mathrm{MsOH}_{\mathrm{s}}\left(1.25 \mathrm{M}\right.$ in $\left.\mathrm{Me} \mathrm{SO}_{2} \mathrm{SO} d_{6}\right)$.

On the other hand, titration of 1 with methanesulfonic acid $(\mathrm{MsOH})$ gave a red-shift absorption band at $489 \mathrm{~nm}$ with an isosbestic point occurring at $442 \mathrm{~nm}$ throughout the titration (see Figure S2 in the Supporting Information). This result indicated that the A-D molecule $\mathbf{1}$ was protonated at the naphthyridine site to form a 1:1 complex with prominent ICT, which prevented further protonation of the di(hydroxyethyl)aniline moiety. The association constant for protonated 1 (1:1 complex of $1-\mathrm{H}^{+}$) was determined to be $355 \pm 70$ in $\mathrm{Me}_{2} \mathrm{SO} / \mathrm{H}_{2} \mathrm{O}(1$ : 1) solution.

In sharp contrast, the $\mathrm{D}-\mathrm{A}-\mathrm{D}$ molecule $\mathbf{2}$ was much more responsive to the $\mathrm{Hg}^{2+}$ ion than the $\mathrm{A}-\mathrm{D}$ molecule $\mathbf{1}$ in the UV-vis titration. The initial addition of $\mathrm{Hg}^{2+}$ ions to 2 caused a prominent new absorption band at $\lambda_{\max }$ $=498 \mathrm{~nm}$ (Figure 2). The yellow solution of $2 \mathrm{im}$ mediately changed to magenta in accordance with this large red-shift $(\Delta \lambda=48 \mathrm{~nm})$. As predicted in Scheme 1b, the $\mathrm{Hg}^{2+}$ ion might either bind to the acceptor site at the early stage of titration to facilitate ICT or bind to one of the donor sites to form an enhanced $\mathrm{A}-\mathrm{D}-\mathrm{Hg}^{2+}$ electronwithdrawing unit that also facilitates the net ICT, resulting in an additive effect in the dipolar change.

The magenta color of the mixture solution faded when more than 10 equiv of $\mathrm{Hg}^{2+}$ ions were added. Accordingly, an extraordinarily large hypsochromic shift $(\Delta \lambda=120$ $\mathrm{nm}$ ) from 498 to $378 \mathrm{~nm}$ was observed. By addition of more than 10 equiv of $\mathrm{Hg}^{2+}$ ions, all the acceptor and donor sites in molecule $\mathbf{2}$ were likely saturated to reach a late stage of complexation (as the MD-AM-DM species in Scheme 1b), in which the saturated complex would only possess the least ICT property. The prohibition of $\pi$ conjugation thus results in a great hypsochromic shift of the absorption band.

(9) Connors, K. A. Binding Constants; Wiley: New York, 1987.
Calculations with Specfit global analysis software (Specfit/32) supported our experimental results of complex formation, i.e., the primary formed 1:1 complex (2$\mathrm{Hg}^{2+}$ ) decreased after addition of 10 equiv of $\mathrm{Hg}^{2+}$ ions, along with the growth of the 1:3 complex, $2-\left(\mathrm{Hg}^{2+}\right)_{3}$. The association constants for $\mathbf{2}-\mathrm{Hg}^{2+}$ and $\mathbf{2}-\left(\mathrm{Hg}^{2+}\right)_{3}$ complexes at $298 \mathrm{~K}$ were estimated to be $(2.82 \pm 0.17) \times 10^{5}$ $\mathrm{M}^{-1}$ and $(8.91 \pm 0.24) \times 10^{11} \mathrm{M}^{-3}$, respectively. The binding strength of receptor 2 toward $\mathrm{Hg}^{2+}$ (1:1 complex) is comparable to that of azatetrathia-15-crown- 5 , $8 \mathrm{cce}$ though a precise comparison is not possible due to the nature of different receptors and variation of measurement methods and media. Furthermore, the association constant of $(2.82 \pm 0.17) \times 10^{5} \mathrm{M}^{-1}$ for $2-\mathrm{Hg}^{2+}$ in $\mathrm{Me}_{2}$ $\mathrm{SO} / \mathrm{H}_{2} \mathrm{O}$ ( $1: 1$ complex) is more than 2 orders of magnitude stronger than that $\left(1490 \pm 31 \mathrm{M}^{-1}\right)$ for $\mathbf{1}-\mathrm{Hg}^{2+}$ at 298 $\mathrm{K}$. The results can be tentatively rationalized by the fact that the $\mathrm{D}-\mathrm{A}-\mathrm{D}$ molecule 2 possesses two ICT sites, the sum of which doubly increase the electron density at naphthyridine in comparison to that of the $\mathrm{A}-\mathrm{D}$ molecule 1. As a result, the binding strength in system 2 is expected to be appreciably higher than that in system $\mathbf{1}$.

A different feature was observed in protonation of $\mathbf{2}$ by adding $\mathrm{MsOH}$. The protonation caused a red-shift of absorption to $560 \mathrm{~nm}$ with an isosbestic point occurring at $483 \mathrm{~nm}$ throughout the titration. Calculations with both Specfit/32 software and nonlinear regression analysis $^{9}$ concluded the 1:1 stoichiometry of $2-\mathrm{H}^{+}$formation. Unlike the two-stage sensing event on titration with $\mathrm{Hg}^{2+}$, addition of excess $\mathrm{MsOH}$ (e.g., 1000 equiv) did not show blue-shifted absorption. It appeared that protonation at the naphthyridine site induced a prominent ICT, which prevented further protonation of the di(hydroxyethyl)aniline moieties. The ${ }^{1} \mathrm{H}$ NMR titration with $\mathrm{MsOH}$ (Figure 3) also clearly showed that the naphthyridine protons $\mathrm{H}-3 / \mathrm{H}-6$ and $\mathrm{H}-4 / \mathrm{H}-5$ shifted to lower fields, 
whereas the protons $\mathrm{H}-2^{\prime}, \mathrm{H}-3^{\prime}, \mathrm{H}-\mathrm{1}^{\prime \prime}$, and $\mathrm{H}-\mathrm{2}^{\prime \prime}$ on the di(hydroxyethyl)aniline moieties were insensitive.

Nonetheless, $\mathrm{MsOH}$ did not interfere with the detection of $\mathrm{Hg}^{2+}$ ion with receptor 2. For example, a brownish purple mixture containing 2 ( 1 equiv) and $\mathrm{MsOH}$ (50 equiv) with $\lambda_{\max }=560 \mathrm{~nm}$ readily changed to magenta with $\lambda_{\max }=507 \mathrm{~nm}$ on addition of $\mathrm{Hg}\left(\mathrm{ClO}_{4}\right)_{2}$ (2 equiv). Addition of over 10 equiv of $\mathrm{Hg}\left(\mathrm{ClO}_{4}\right)_{2}$ resulted in the growth of 379-nm absorption, similar to the spectra shown in Figure 2. We also found that the sensing events of 2 with $\mathrm{Hg}^{2+}$ ions occurred similarly in $\mathrm{Me}_{2} \mathrm{SO} / \mathrm{HEPES}$ buffer solutions at $\mathrm{pH} 5.55$ and 7.28.

Molecule 2 was insensitive to alkaline ions (e.g., $\mathrm{Mg}^{2+}$, $\mathrm{Ca}^{2+}$, and $\mathrm{Ba}^{2+}$ ), transition metal ions (e.g., $\mathrm{Mn}^{2+}$ and $\mathrm{Fe}^{2+}$ ), or the toxic ions (e.g., $\mathrm{Co}^{2+}, \mathrm{Ni}^{2+}, \mathrm{Cu}^{2+}, \mathrm{Zn}^{2+}, \mathrm{Cd}^{2+}$, and $\mathrm{Pb}^{2+}$ ). The UV-vis spectrum of $\mathbf{2}$ showed no obvious change by treatments with any of the above-mentioned metal ions, even in very large quantities (e.g., 200 equiv). A mixture containing 2 ( 1 equiv) and metal ions (each 200 equiv) other than $\mathrm{Hg}^{2+}$ retained its yellow color $\left(\lambda_{\max }\right.$ $=450 \mathrm{~nm})$, but changed instantly to magenta $\left(\lambda_{\max }=502\right.$ $\mathrm{nm}$ ) upon addition of $\mathrm{Hg}^{2+}$ ion. When more than 10 equiv of $\mathrm{Hg}^{2+}$ ions were added, the color faded and the absorption band also shifted to $378 \mathrm{~nm}$. Thus, the two-stage colorimetric property of $\mathbf{2}$ was unique in the detection of the $\mathrm{Hg}^{2+}$ ion in aqueous media, e.g., $\mathrm{Me}_{2} \mathrm{SO} / \mathrm{H}_{2} \mathrm{O}$ (1:1), free from the interference of other metal ions. The unique selectivity of $\mathrm{Hg}^{2+}$ based on the current system is truly remarkable. At the current stage, although the actual cause of the $\mathrm{Hg}^{2+}$ selectivity is pending resolution, we tentatively propose that $\mathrm{Hg}^{2+}$ tends to bind molecule 2 (or 1) with the naphthyridine chromophore at the first stage, whereas such a binding strength is rather weak for the other metal ions studied. This viewpoint may be rationalized by a very specific orientation of electron density for two pyridinyl lone-pair electrons in the naphthyridine moiety. As a result, naphthyridine favors a complex formation with a soft metal ion of large radius such as $\mathrm{Hg}^{2+}$. Further firm support has been given in the NMR titration studies (vide supra), in which the major changes of proton signals occur at the naphthyridine sites in the early stage of the titration with $\mathrm{Hg}^{2+}$ ions.

In conclusion, the dual-armed $\mathrm{D}-\mathrm{A}-\mathrm{D}$ molecule $\mathbf{2}$ exhibits absorptions at longer wavelengths than the $\mathrm{A}-\mathrm{D}$ molecule 1, and hence provides a more convenient "naked-eye" colorimetric detection of the $\mathrm{Hg}^{2+}$ ion. Instead of the commonly used macrocycles for metal ion detection, ${ }^{1,2,8}$ molecule $\mathbf{2}$ with the acyclic di(hydroxyethy1)aniline components renders a straightforward preparation and good solubility in aqueous media. The D-A-D constitution demonstrated in this study can serve as a protocol for the future design of a multiple-stage sensing system, which may eventually lead to practical application on the logic gates ${ }^{4 c, 10}$ based on its sensitivity and selectivity of metal ions and other possible analytes.

\section{Experimental Section}

$\boldsymbol{N}, \boldsymbol{N}$-Di(2-hydroxyethyl)-4-ethynylaniline (3). Under an atmosphere of nitrogen, a mixture of 4-iodoaniline (1.3 g, 6

(10) (a) de Silva, A. P.; Dixon, I. M.; Gunaratne, H. Q. N.; Gunnlaugsson, T.; Maxwell, P. R. S.; Rice, T. E. J. Am. Chem. Soc. 1999, 121, 1393-1394. (b) de Silva, A. P.; Fox, D. B.; Huxley, A. J. M.; Moody, T. S. Coord. Chem. Rev. 2000, 205, 41-57. mmol), 2-chloroethanol (10 mL), and $\mathrm{K}_{2} \mathrm{CO}_{3}$ (4 g, $\left.30 \mathrm{mmol}\right)$ was heated at $55^{\circ} \mathrm{C}$ for $10 \mathrm{~h}$. The mixture was concentrated, brine was added $(40 \mathrm{~mL})$, and the solution was extracted with $\mathrm{CH}_{2^{-}}$ $\mathrm{Cl}_{2}$. The combined organic phase was dried $\left(\mathrm{Na}_{2} \mathrm{SO}_{4}\right)$, filtered, and concentrated under reduced pressure to give a crude product. After recrystallization from EtOAc, $N, N$-di(2-hydroxyethyl)-4-iodoaniline (1.3 g, 71\% yield) was obtained as yellow crystals, mp $71-72{ }^{\circ} \mathrm{C}$.

Under an atmosphere of argon, a mixture of $N, N$-di(2hydroxyethyl)-4-iodoaniline (370 mg, $1.2 \mathrm{mmol}$ ), (trimethylsilyl)acetylene $(0.2 \mathrm{~mL}, 1.44 \mathrm{mmol}), \mathrm{Et}_{3} \mathrm{~N}(2 \mathrm{~mL}), \mathrm{PdCl}_{2}\left(\mathrm{PPh}_{3}\right)_{2}$ (10 $\mathrm{mg}, 0.014 \mathrm{mmol}$ ), and $\mathrm{CuI}(3 \mathrm{mg}, 0.016 \mathrm{mmol})$ in $1,4-$ dioxane $(2 \mathrm{~mL})$ was heated at $50-55^{\circ} \mathrm{C}$ for $14 \mathrm{~h}$. The mixture was concentrated, taken by $\mathrm{MeOH} / \mathrm{CH}_{2} \mathrm{Cl}_{2}$ (1:9), and passed through a short column of Celite by elution with $\mathrm{MeOH} / \mathrm{CH}_{2^{-}}$ $\mathrm{Cl}_{2}$. The organic phase was concentrated, and the crude product was purified by silica gel chromatography $\left(\mathrm{MeOH} / \mathrm{CH}_{2^{-}}\right.$ $\mathrm{Cl}_{2}$ (1:9)) to give $N, N$-di(2-hydroxyethyl)-4-(trimethylsilyl)ethynylaniline (303 mg, 91\% yield) as yellow solids, mp 96$97{ }^{\circ} \mathrm{C}$.

A solution of $N, N$-di(2-hydroxyethyl)-4-(trimethylsilyl)ethynylaniline (300 mg, $1.08 \mathrm{mmol})$ in $\mathrm{MeOH}(5 \mathrm{~mL})$ was treated with $\mathrm{K}_{2} \mathrm{CO}_{3}$ (443 mg, $3.24 \mathrm{mmol}$ ). The mixture was stirred at room temperature for $1 \mathrm{~h}$, then concentrated under reduced pressure. The residue was purified by silica gel column chromatography with elution of $\mathrm{MeOH} / \mathrm{CH}_{2} \mathrm{Cl}_{2}$ (1:9) to give compound 3 (200 $\mathrm{mg}, 90 \%$ yield) as pale yellow solids.

3: $\mathrm{mp} 107-108{ }^{\circ} \mathrm{C}$; $\mathrm{TLC}\left(\mathrm{MeOH} / \mathrm{CH}_{2} \mathrm{Cl}_{2}(1: 19)\right) R_{f} 0.20$; IR (KBr) 3300, 2929, 2098, $1517 \mathrm{~cm}^{-1} ;{ }^{1} \mathrm{H} \mathrm{NMR}\left(\mathrm{CDCl}_{3}, 400 \mathrm{MHz}\right)$ $\delta 7.32(2 \mathrm{H}, \mathrm{d}, J=8.9 \mathrm{~Hz}), 6.56(2 \mathrm{H}, \mathrm{d}, J=8.9 \mathrm{~Hz}), 3.79(4$ $\mathrm{H}, \mathrm{t}, J=4.8 \mathrm{~Hz}), 3.54(4 \mathrm{H}, \mathrm{t}, J=4.8 \mathrm{~Hz}), 2.96(1 \mathrm{H}, \mathrm{s}) ;{ }^{13} \mathrm{C}$ $\mathrm{NMR}\left(\mathrm{CDCl}_{3}, 100 \mathrm{MHz}\right) \delta 147.9,133.3(2 \times), 111.9(2 \times), 109.4$, 84.4, 75.1, $60.5(2 \times), 55.1(2 \times)$; FAB-MS $m / z 206.1\left(\mathrm{M}^{+}+\right.$ $\mathrm{H})$; HRMS calcd for $\mathrm{C}_{12} \mathrm{H}_{16} \mathrm{NO}_{2}\left(\mathrm{M}^{+}+\mathrm{H}\right) 206.1181$, found $\mathrm{m} / z$ 206.1180 .

7-\{4-[Di(2-hydroxyethyl)amino]phenylethynyl $\}-1,8$ naphthyridine (1). Under an atmosphere of argon, a mixture of 2-chloronaphthyridine ( $50.2 \mathrm{mg}, 0.305 \mathrm{mmol}), \mathrm{Et}_{3} \mathrm{~N}(1 \mathrm{~mL})$, $\mathrm{PdCl}_{2}\left(\mathrm{PPh}_{3}\right)_{2}(21 \mathrm{mg}, 0.0305 \mathrm{mmol})$, and $\mathrm{CuI}(5 \mathrm{mg}, 0.0305$ $\mathrm{mmol}$ ) in DMF (3 mL) was heated at $80-85^{\circ} \mathrm{C}$ for $10 \mathrm{~min}$. A solution of $N, N$-di(2-hydroxyethyl)-4-ethynylaniline $(\mathbf{3}, 74.7$ $\mathrm{mg}, 0.366 \mathrm{mmol}$ ) in DMF (3 $\mathrm{mL}$ ) was added dropwise, and the mixture was heated for another $18 \mathrm{~h}$. The mixture was concentrated, and the crude product was purified by silica gel chromatography $\left(\mathrm{MeOH} / \mathrm{CH}_{2} \mathrm{Cl}_{2}(1: 9)\right)$ to give compound $\mathbf{1}$ (87 $\mathrm{mg}, 82 \%$ yield) as yellow solids.

1: $\mathrm{mp} 185-185.9{ }^{\circ} \mathrm{C}$; TLC ( $\left.\mathrm{MeOH} / \mathrm{CH}_{2} \mathrm{Cl}_{2}(1: 9)\right) R_{f} 0.31$; IR (KBr) 3421, 2931, 2202, $1594 \mathrm{~cm}^{-1}$; UV-vis $\left(\mathrm{Me}_{2} \mathrm{SO} / \mathrm{H}_{2} \mathrm{O}(1\right.$ : 1)) $\lambda_{\max } 409 \mathrm{~nm}\left(\epsilon=45000 \mathrm{M}^{-1} \mathrm{~cm}^{-1}\right) ;{ }^{1} \mathrm{H}$ NMR (DMSO- $d_{6}$, $400 \mathrm{MHz}) \delta 9.08(1 \mathrm{H}, \mathrm{d}, J=8.0 \mathrm{~Hz}), 8.44(2 \mathrm{H}, \mathrm{d}, J=8.4$ $\mathrm{Hz}), 7.73(1 \mathrm{H}, \mathrm{d}, J=8.4 \mathrm{~Hz}), 7.60(1 \mathrm{H}, \mathrm{dd}, J=8.4,8.0 \mathrm{~Hz})$, $7.45(2 \mathrm{H}, \mathrm{d}, J=8.7 \mathrm{~Hz}), 6.76(2 \mathrm{H}, \mathrm{d}, J=8.7 \mathrm{~Hz}), 4.80(2 \mathrm{H}$, $\mathrm{t}, J=4.8 \mathrm{~Hz}), 3.56(4 \mathrm{H}, \mathrm{td}, J=5.2,4.8 \mathrm{~Hz}), 3.48(4 \mathrm{H}, \mathrm{t}, J=$ $4.8 \mathrm{~Hz}$ ); ${ }^{13} \mathrm{C}$ NMR (DMSO- $\left.d_{6}, 100 \mathrm{MHz}\right) \delta 155.5,154.3,149.2$, $146.5,138.0,137.4,133.5(2 \times), 125.0,122.3,121.5,111.5(2$ $\times), 105.9,93.7,88.2,58.0(2 \times), 53.1(2 \times) ;$ FAB-MS $\mathrm{m} / z 368.1$ $\left(\mathrm{M}^{+}+\mathrm{H}\right)$; HRMS calcd for $\mathrm{C}_{20} \mathrm{H}_{20} \mathrm{~N}_{3} \mathrm{O}_{2}\left(\mathrm{M}^{+}+\mathrm{H}\right) 334.1556$, found $\mathrm{m} / \mathrm{z}$ 364.1548. Anal. Calcd for $\mathrm{C}_{20} \mathrm{H}_{19} \mathrm{~N}_{3} \mathrm{O}_{2}$ : C, 72.05; $\mathrm{H}$, $5.74 ; \mathrm{N}, 12.60$. Found: C, 71.88; H, 5.92; N, 12.41 .

2,7-Bis $\{4$-[di(2-hydroxyethyl)amino]phenylethynyl $\}$ 1,8-naphthyridine (2). Under an atmosphere of argon, a mixture of 2,7-dichloronaphthyridine ( $48 \mathrm{mg}, 0.24 \mathrm{mmol}), \mathrm{Et}_{3} \mathrm{~N}$ $(1 \mathrm{~mL}), \mathrm{PdCl}_{2}\left(\mathrm{PPh}_{3}\right)_{2}(16 \mathrm{mg}, 0.023 \mathrm{mmol})$, and $\mathrm{CuI}(3 \mathrm{mg}$, $0.016 \mathrm{mmol}$ ) in DMF (5 mL) was heated at $80-85{ }^{\circ} \mathrm{C}$ for 10 min. A solution of $N, N$-di(2-hydroxyethyl)-4-ethynylaniline (105 mg, $0.51 \mathrm{mmol}$ ) in DMF (3 mL) was added dropwise, and the mixture was heated for another $13 \mathrm{~h}$. The mixture was concentrated, taken by $\mathrm{MeOH} / \mathrm{CH}_{2} \mathrm{Cl}_{2}$ (1:9), and passed through a short column of Celite by elution with $\mathrm{MeOH} / \mathrm{CH}_{2} \mathrm{Cl}_{2}$. The organic phase was concentrated, and the crude product was purified by silica gel chromatography $\left(\mathrm{MeOH} / \mathrm{CH}_{2} \mathrm{Cl}_{2}(1: 9)\right)$ to give compound 2 (98 $\mathrm{mg}, 77 \%$ yield) as red solids. 
2: $\mathrm{mp}>300{ }^{\circ} \mathrm{C} \mathrm{dec}$; TLC $\left(\mathrm{MeOH} / \mathrm{CH}_{2} \mathrm{Cl}_{2}(1: 9)\right) R_{f}$ 0.26; IR (KBr) $3320,2928,2202,1588 \mathrm{~cm}^{-1}$; UV-vis spectrum $\lambda_{\max } 332$ $\mathrm{nm}\left(\epsilon=29000 \mathrm{M}^{-1} \mathrm{~cm}^{-1}\right), \lambda_{\max }=450 \mathrm{~nm}\left(\epsilon=54000 \mathrm{M}^{-1}\right.$ $\mathrm{cm}^{-1}$ ) in $\mathrm{Me}_{2} \mathrm{SO} / \mathrm{H}_{2} \mathrm{O}(1: 1) ;{ }^{1} \mathrm{H}$ NMR (DMSO- $\left.d_{6}, 400 \mathrm{MHz}\right) \delta$ $8.39(2 \mathrm{H}, \mathrm{d}, J=8.3 \mathrm{~Hz}), 7.68(2 \mathrm{H}, \mathrm{d}, J=8.3 \mathrm{~Hz}), 7.45(4 \mathrm{H}$, $\mathrm{d}, J=8.8 \mathrm{~Hz}), 6.77(4 \mathrm{H}, \mathrm{d}, J=8.8 \mathrm{~Hz}), 4.81(4 \mathrm{H}, \mathrm{t}, J=5.5$ $\mathrm{Hz}), 3.55(8 \mathrm{H}, \mathrm{t}, J=5.5 \mathrm{~Hz}), 3.49-3.47(8 \mathrm{H}, \mathrm{m}) ;{ }^{13} \mathrm{C}$ NMR $\left(\right.$ DMSO- $\left.d_{6}, 100 \mathrm{MHz}\right) \delta 155.5,149.2(2 \times), 147.1(2 \times), 137.6$ $(2 \times), 133.6(4 \times), 125.0(2 \times), 120.5,111.5(4 \times), 105.9(2 \times)$, $94.1(2 \times), 88.4(2 \times), 58.1(4 \times), 53.1(4 \times)$; FAB-MS $m / z 537.3$ $\left(\mathrm{M}^{+}+\mathrm{H}\right)$; HRMS calcd for $\mathrm{C}_{32} \mathrm{H}_{33} \mathrm{~N}_{4} \mathrm{O}_{4}\left(\mathrm{M}^{+}+\mathrm{H}\right)$ 537.2502, found $m / z$ 537.2496. Anal. Calcd for $\mathrm{C}_{32} \mathrm{H}_{32} \mathrm{~N}_{4} \mathrm{O}_{4}$ : C, 71.62; $\mathrm{H}$, $6.01 ; \mathrm{N}, 10.44$. Found: C, $71.55 ; \mathrm{H}, 6.08 ; \mathrm{N}, 10.36$.

UV-Vis Titration of Compounds 1 and 2 with $\mathbf{H g}^{2+}$ Ions. The stock solution of compound $1\left(1 \times 10^{-5} \mathrm{M}\right)$ was prepared by using spectroscopic grade $\mathrm{Me}_{2} \mathrm{SO}$ and distilled water $(\mathrm{v} / \mathrm{v} 1: 1)$. The solution of $\mathrm{Hg}^{2+}$ ions $\left(1 \times 10^{-2} \mathrm{M}\right)$ was prepared by using mercury(II) perchlorate hydrate dissolved in distilled water. The solutions of $\mathbf{1}$ in the range of $1 \times 10^{-5}$ to $6.25 \times 10^{-5} \mathrm{M}$ exhibited a linear dependence of absorbance. The absorption spectrum of $\mathbf{1}\left(2 \mathrm{~mL}\right.$ of $1 \times 10^{-5} \mathrm{M}$ stock solution) in a quartz cell ( $1 \mathrm{~cm}$ width) was recorded at $298 \mathrm{~K}$. The stock solution of $\mathrm{Hg}^{2+}$ ions was introduced in an incremental fashion $(1,2,3,4,5,6,7,8,9,10,11,12,13$, and 14 $\mu \mathrm{L} ; 2 \mu \mathrm{L}$ corresponds to 1 equiv), and their corresponding UVvis curves were recorded.

The UV-vis titration of 2 with $\mathrm{Hg}^{2+}$ ions was carried out by a procedure similar to that for 1, except for a slight change of $\mathrm{Hg}^{2+}$ increments $(2,4,6,8,10,12,14,16,18,20,22,24,28$, $32,36,40,56,64,72,80,90,100$, and $120 \mu \mathrm{L} ; 2 \mu \mathrm{L}$ corresponds to 1 equiv).

${ }^{1} \mathrm{H}$ NMR Titration of Compounds 1 and 2 with $\mathbf{H g}^{2+}$ Ions or MsOH. The stock solution of $2\left(2.5 \times 10^{-3} \mathrm{M}\right)$ was prepared by using $\mathrm{Me}_{2} \mathrm{SO}-d_{6}$. The $\mathrm{Hg}^{2+}$ solution was prepared as $0.25 \mathrm{M}$ by using the perchlorate salt dissolved in $\mathrm{CD}_{3} \mathrm{CN}$. The solution containing compound $2(0.5 \mathrm{~mL}$ of stock solution) was placed in an NMR tube, and the ${ }^{1} \mathrm{H}$ NMR spectrum was recorded at $298 \mathrm{~K}$. The stock solution of $\mathrm{Hg}^{2+}$ ions was introduced in an incremental fashion $(0.5,1.0,1.5,2.0,2.5$, $3.0,4.0,6.0,10$, and $16 \mu \mathrm{L} ; 5 \mu \mathrm{L}$ corresponds to 1 equiv), and their corresponding ${ }^{1} \mathrm{H}$ NMR spectra were recorded.

The ${ }^{1} \mathrm{H}$ NMR titration of $2\left(2.5 \times 10^{-3} \mathrm{M}\right.$ in $\left.\mathrm{Me}_{2} \mathrm{SO}-d_{6}\right)$ with $\mathrm{MsOH}$ was conducted similarly by incremental additions of $\mathrm{MsOH}\left(1.25 \mathrm{M}\right.$ in $\left.\mathrm{Me}_{2} \mathrm{SO}-d_{6}\right)$.

The ${ }^{1} \mathrm{H}$ NMR titration of $1\left(0.5 \mathrm{~mL}\right.$ of $5 \times 10^{-4} \mathrm{M}$ solution in $\mathrm{Me}_{2} \mathrm{SO}-d_{6}$ ) with $\mathrm{Hg}^{2+}$ ions was carried out by a procedure similar to that for 2 . The stock solution of $\mathrm{Hg}^{2+}$ ions was introduced in an incremental fashion $(0.5,1.0,1.5,2.0$, and $4.0 \mu \mathrm{L} ; 1 \mu \mathrm{L}$ corresponds to 1 equiv).

The binding constant was calculated according to the following equation.

$$
y=[d /(2 c)]\left\{K^{-1}+c+x-\left[\left(K^{-1}+c+x\right)^{2}-4 c x\right]^{0.5}\right\}
$$

where $c$ is the receptor concentration, $d$ the saturated chemical shift, $K$ the association constant, $x$ the substrate concentration, and $y$ the chemical shift.

Acknowledgment. We thank the National Science Council for financial support.

Supporting Information Available: NMR spectra, UVvis titration curves and figures. This material is available free of charge via the Internet at http://pubs.acs.org.

JO050389E 